\title{
Metaverse and changes in oral health
}

\author{
Cho Hyun-Jae
}

Academic Director of the Korean Academy of Preventive Dentistry and Oral Health

With the emergence of the concept of metaverse, where we can not only communicate with people (other users of the metaverse) but also work in virtual spaces, scholars in the field of pedagogy are seriously discussing how metaverses will affect education. Recently, the Korean Academy of Science Education held a summer academic conference on a metaverse platform called Gether Town.

For mankind, education has become the foundation for the development of civilization. It is said that the first educational revolution was the invention of letters, the second was the provision of group education, and the third was provision of group education through online lectures. Furthermore, it is said that the fourth educational revolution will enable super-customized education that is tailored to individual learning capabilities and achievements with technologies such as Artificial Intelligence (AI), Virtual Reality (VR), and metaverse.

Until now, oral health education has been conducted in groups at public health centers and schools. However, it has not been possible to provide oral health education individually, according to the capacities of each individual, and due to the recent COVID-19 pandemic, oral health group education remains to be implemented. Currently, there is a growing demand for oral health education using non-face-to-face platforms such as ZOOM.

In the near future, oral health education may be provided using ZOOM, but in the longer term, I believe we will witness an era of group and individually customized oral health education using platforms that feel more real, such as metaverse.

Previously, this was expensive and difficult to implement, whether by the government or the private sector. However, currently, with the changes in perception and the advances in technology, non-face-to-face connections are possible, and the cost is very low. With this trend, I believe the barriers between the government and the private sector will break down, and the question of who can provide better value will become more important. In this context, oral health researchers should also study the changing circumstances and issues with interest.

December 2021 


\section{메타버스와 구강보건학의 변화}

조현재

대한예방치과 · 구강보건학회 학술이사

가상공간에서 사람끼리 소통을 할 뿐 만 아니라 업무를 할 수 있게 되는 메타버스란 개념이 나오면서, 교육학 분야에서는 메타버스라 는 것이 교육에 대해서 어떠한 영향을 미칠지 진지하게 논의를 하고 있다. 최근 한국과학교육학회에서는 게더타운이란 메타버스 업무 플 랫폼에 하계학술대회를 개최하기도 하였다.

인류에게 교육이란 문명을 발전시킬 수 있는 토대가 되었다. 1 차 교육혁명은 문자의 발명이고, 2 차 교육혁명은 집단교육을 할 수 있 게 되었으며, 3 차 교육혁명은 이 집단 교육을 인터넷으로 온라인 강의들이 가능해진 것이라고 한다. 여기에 4차 교육혁명으로 AI나 VR, 메타버스와 같은 기술들로 개개인의 학습역량과 성취에 맞는 초맞춤형(super customization) 교육이 가능해진다라고 한다.

구강보건학에서도 대상자에 대한 교육을 중요시 여긴다. 그동안 보건소나 학교에서 구강보건교육을 집단으로 해왔으나 사실 개개인 에 대한 수준에 맞춰서 개별적으로 하는 것은 불가능했을 뿐 만 아니라 최근에 코로나 이슈로 집단 구강보건교육은 아애 실시가 되지 않고 있다. 이제는 ZOOM과 같은 비대면 플랫폼을 이용한 구강보건교육에 대한 요구도가 커지고 있다.

가까운 미래에는 ZOOM을 이용하여 구강보건교육을 할 수도 있겠지만 조금 더 장기적으로 보면 메타버스와 같은 조금 더 실제와 같 은 느낌을 주는 플랫폼을 이용하여 집단적이면서도 개별적인 맞춤 구강보건교육을 받는 시대가 오지 않을까 생각한다.

이러한 방식은 비용이 많이 들어서 정부든 민간이든 누구도 할 수가 없는 것이었다. 이제는 인식의 변화와 기술의 발전으로 비대면 방 식의 연결이 가능해졌고, 비용도 매우 적게 들어간다. 이러한 흐름 속에서 생각을 하면 정부와 민간이 할 일을 정했던 방식과 경계가 허물 어지고, 누가 하느냐가 중요한 것이 아니라 누가 더 가치를 잘 제공할 수 있느냐가 중요해지지 않을까 생각한다. 그러한 점에서 우리 구강 보건학에서도 이러한 변화하는 상황과 이슈에 대해서 관심을 갖고 연구를 해야될 것으로 보인다.

2021. 12 . 